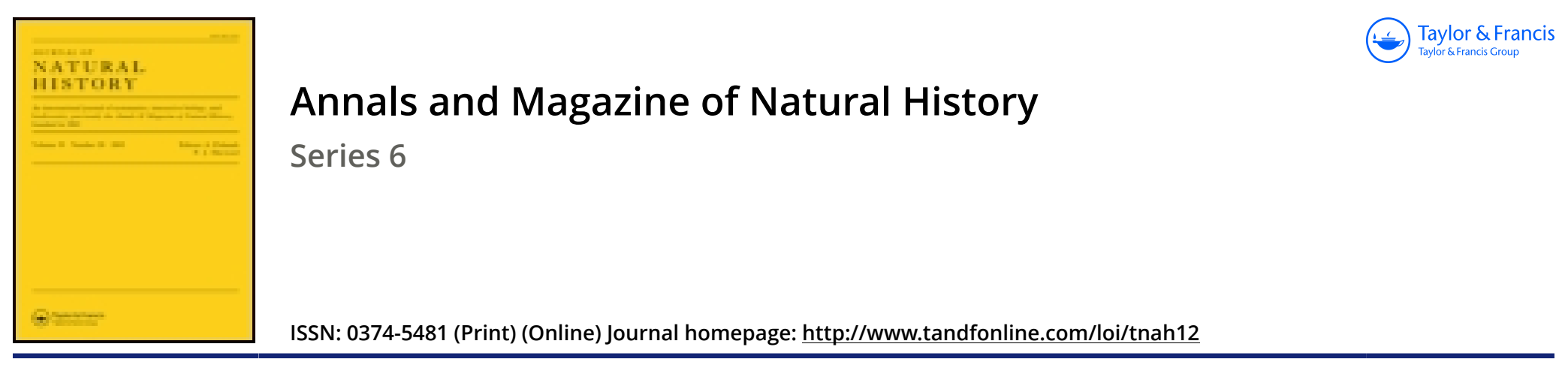

\title{
XXXII.-Note on Tenebrio ferrugineus, Fabr., in the Banksian Collection of Coleoptera
}

\section{Charles O. Waterhouse}

To cite this article: Charles O. Waterhouse (1896) XXXII.-Note on Tenebrio ferrugineus, Fabr., in the Banksian Collection of Coleoptera, Annals and Magazine of Natural History, 17:99, 230-231, DOI: $10.1080 / 00222939608680356$

To link to this article: http://dx.doi.org/10.1080/00222939608680356

曲 Published online: 06 Oct 2009.

Submit your article to this journal $\sqsubset \pi$

Џ Article views: 3

Q View related articles $\asymp$ 
XXXII.-Note on Tenebrio ferrugineus, Fabr., in the Banksian Collection of Coleoptera. By Chardes 0 . WATERHOUSE.

I HAVE had occasion to examine the type specimen of Tenebrio ferrugineus, F. (Sp. Ins. i. p. 324), and think the following notes may be useful.

The following is the Fabrician description:- "Corpus præcedenti [Antherophagus pallens] adhuc minus, magis depressum ferrugineum. Elytra striata, testacea. Habitat in Africa æquinoctiali."

The general appearance is something between Pediacus and Lamophlous; the antennæ, however, resemble those of Gnathocerus, but with longer terminal joint. I cannot call to mind any insect with a similar thorax. This is flat, slightly dull, except the smooth median line and fine smooth line inside the lateral finely reflexed margin; it is only slightly narrowed towards the base, and the almost rectilinear sides are peculiar. I can only distinguish four joints to all the tarsi.

I think the species must be placed in the Cucujidx, near Xenoscelis, Woll., which it resembles in many respects, but has quite different antennæ.

The following additional characters will help to identify the species. Of course the insect so long known in our collections as Tribolium "ferrugineum, Fab.," will have to bear a different specific name.

Prosternum without process, flat between the coxæ, impressed behind them. Mesosternum lightly impressed, with a slight oblique sweling next the intermediate coxæ, which are moderately separated; the line dividing the mesosternum from metasternum curved. Metasternum with a deep longitudinal median impression behind. [Abdomen wanting:] Apical joint of the maxillary palpi elongate-ovate, very obliquely truncate at the apex.

Anterior tarsus four-jointed, four fifths the length of the tibia. The basal joint about one third of the tarsus; the second and third joints shorter, subequal, slightly produced beneath ; claw-joint a very little longer than the basal joint.

Posterior tarsus with four joints, the basal one long; the second with its basal part about one third the length of the basal joint, produced below into a long rather broad lamina, extending beneath to about the middle of the claw-joint; the third joint about as long as the second; the claw-joint about 
as long as the basal joint. The eyes are rather large and very coarsely faceted. The antennm are as long as the head and thorax together, slightly flattened. The basal joint a little longer than broad; second joint very short ; third joint about one third longer than broad, narrowed towards its base; the fourth to tenth joints subequal, shorter than the third, very slightly increasing in width; the terminal joint as long as the two preceding joints taken together, elongate-ovate, rather narrowed towards the apex. Head somewhat as in Pediacus, but flatter, less narrowed in front, narrowed behind the eyes, but with a distinct portion behind the eye; surface rather strongly and rather closely punctured. Thorax broader than the head, about as long as broad, rather flat, irregularly and rather strongly punctured (with a fine smooth median line), broadest just before the front angles, gradually but not very much narrowed to the base; the sides almost rectilinear, finely margined; the posterior angles slightly projecting and acute; the base with two widely separated sharply marked fover. Elytra somewhat as in Pediacus, each with the suture and three fine costa slightly raised; the intervals flat and appearing smooth, but there are a few fine obscure punctures.

XXXIII.-Note on the Synonymy of Huphina lanassa, a common Australian Butterfly of the Subfamily Pierinæ. By Arthur G. Butler, Ph.D. \&c.

So much confusion has arisen in the synonymy of this species that, after carefully working it out, I feel no time should be lost in putting it straight.

The species was described by M. Boisduval in his 'Species Géneral " (1836), evidently from an old temale example from New Holland in which the under surface of the secondaries had darkened to ochreous with age, and in which there chanced to be no submarginal spots (we have a specimen in which the secondaries show only one spot on the under surface).

M. Boisduval considered his specimen to be a male; but he so often blundered in sexing his species, that no reliance can be placed upon the statement " Nous n'avons pas vu la femelle." The description " la bordure des supérieures assez large" can hardly apply to a male, unless it be assumed that his method of description was loose, because an equally broad border to 